\title{
THE IMAGE OF JESUS IN THE RUSSIAN REVOLUTIONARY MOVEMENT
}

\author{
THE CASE OF RUSSIAN MARXISM*
}

Summary: This article explores how Russian revolutionaries, in particular the Russian Marxists, used the image of Jesus to explain their political choices and commitments. These revolutionaries were almost uniformly hostile to institutional Christianity. Yet a number of Russian Marxists, such as Anatolii Lunacharskii, considered Jesus a genuine precursor of socialism. In 1917 many Bolsheviks and Bolshevik sympathizers interpreted the October Revolution in Christian terms, principally as a spiritual resurrection and rebirth. And in 1924, following Lenin's death, some Bolsheviks analogized Lenin to Jesus, and claimed that both were revolutionary martyrs. Finally, the article argues that Russian revolutionaries invested the Russian lower classes with a Christlike virtue, making it easier for the revolutionaries, once in power, to justify everything they did as advancing the interests of these classes.

It is often said that the Russian revolutionary movement professed values that are, in the broadest sense of the word, religious. The emphasis on the perfectibility of man and on the moral transformation of the individual, the glorification of self-sacrifice and martyrdom, the belief in a Golden Age at the end of history bringing with it collective regeneration and rebirth - all these attributes of Russian radical politics from roughly 1840 to 1930 attest to the influence of religious values, if not of religious beliefs, in the development of revolutionary ideology. Indeed, one may speak of the Marxist scheme of history, which had special appeal in Russia beginning in the 1890 's, as following in many significant respects the scenario of Christianity. As Alasdair MacIntyre has observed, Marxism and Christianity both present a "world-historical drama" in which defeat leads to triumph, weakness to strength, and powerlessness to power, with mankind ultimately recovering the moral purity it has lost so that it can live in a state of grace that has replaced, and transcended, historical time. ${ }^{1}$

Some of those who have pointed out the similarities between religion and revolution were themselves one-time revolutionaries who subsequently repudiated their radical beliefs. ${ }^{2}$ Understandably, many of these have

* The author wishes to acknowledge the assistance of Julie Barsel, George Kline, and Marshall Shatz in the preparation of this article.

1 Alasdair MacIntyre, Marxism and Christianity (New York, 1968), p. 111.

2 See, for example, Richard Crossman (ed.), The God That Failed (London, 1949). 
viewed revolution - both as a political objective and as a method of politics - as a perversion of religious faith. In Russia, Nikolai Berdiaev, Sergei Bulgakov, and Semën Frank contributed to a collection of essays called $V e k h i$, published in 1909 , in which the authors criticized what they saw as the rationalism, utilitarianism, moral relativism, and philosophical materialism of the revolutionary movement. Although these are all, to one degree or another secular notions, the fervor with which the revolutionary movement embraced them seemed to the contributors to Vekhi to be a form of religious conviction; even the atheism of the revolutionary movement was a matter of faith for it. But the contributors also maintained that, without a belief in God, the revolutionaries lost all sense of their fallibility as creations of God and believed that, through revolution, they could create a Kingdom of Heaven on earth. Because of their atheism, their fervor became fanaticism, their moral rigor produced intolerance and arrogance, and their willingness to sacrifice themselves for a higher purpose justified sacrificing others as well. ${ }^{3}$

One does not have to agree with everything the Vekhi authors wrote about revolution to acknowledge that they were right in pointing out aspects of Russian revolutionary politics - particularly the utopianism, the idealism, and the capacity for martyrdom - that are reminiscent of religious faith. What remains to be explored, however, is whether these qualities reminiscent of religious faith were also a genuine expression of religious faith. Were there Russian revolutionaries for whom religion and, in particular, Christianity played a major role in the genesis, development, and refinement of their political beliefs? Could religious impulses have motivated even the revolutionaries who explicitly denied the validity of religion and religious experience in their memoirs and reminiscences and who declared themselves to be atheistic, agnostic, or simply indifferent? Or did religion simply provide a vocabulary for the expression of revolutionary convictions that originated elsewhere, in the interplay of family and individual psychology, or in the political and economic circumstances of the time? Or would the answers to these questions depend upon which phase of the revolutionary movement, the populist or the Marxist, one was referring to?

${ }^{3}$ Nikolai Berdiaev, "Philosophical Verity and Intelligentsia Truth"; Sergei Bulgakov, "Heroism and Asceticism (Reflections on the Religious Nature of the Russian Intelligentsia)", and Semën Frank, "The Ethic of Nihilism (A Characterization of the Russian Intelligentia's Moral Outlook)", in Signposts: A Collection of Articles on the Russian Intelligentsia, translated and edited by Marshall S. Shatz and Judith E. Zimmerman (Irvine, CA , 1986), pp. 1-49, 131-155. Although the contributors to Signposts directed their criticisms at the intelligentsia, it is clear that they believed the intelligentsia gave rise to the revolutionary movement and was the ultimate source of its basic attitudes and outlook. 
One way of addressing these questions is by examining how Russian Marxists viewed Jesus himself, unquestionably the central figure in Christianity. Did the Russian Marxists have much to say about Jesus? Did the antipathy most of them felt towards institutional Christianity preclude their praising Jesus, or even identifying with him? And if they identified with Jesus, or analogized their situation to his, was this a reflection of the ideas he preached, or was it a consequence of the economic deprivation and political powerlessness of his original disciples? Or would identification with Jesus have more to do with his resurrection and divinity, recognition of which might provide Russian Marxists with the same sense of invincibility that enabled the earliest Christians to confront, and ultimately to survive, the Roman Empire? Finally, what value did the image of Jesus have for the Marxists who, after 1917, found themselves in power in Russia? Were they all, like Lenin, implacably hostile to all expressions of Christianity, or did the image of Jesus have some relevance to the task of constructing a New Soviet Man, whose attributes would include a capacity for physical immortality, resurrection, and rejuvenation?

Drawing on the past for symbolism, inspiration, and legitimacy is common practice among revolutionaries, and in this respect the Russians were no exception - German socialists such as Ferdinand Lassalle allowed cults of themselves to develop that were strikingly similar to the Roman Catholic veneration of saints. ${ }^{4}$ Indeed, historians already have explored the analogies Russian revolutionaries suggested between their own activities and the American and French Revolutions. ${ }^{5}$ But the possibility that the Russians also identified with Jesus and Gospel Christianity raises issues bearing upon the moral justification of revolution that are largely absent in the analogies they drew with primarily secular events like the American and French Revolutions. It seems appropriate to ask whether a familiarity with Jesus caused the revolutionaries to act, and to justify their actions, in ways they would not have if they had ignored him entirely. It is the purpose of this article to ascertain exactly how Russian revolutionaries, and particularly Russian Marxists, viewed Jesus, to explain why they did so, and to indicate whatever lessons of a moral and political nature they drew from him.

In the writings of Russian revolutionaries of the nineteenth century, Jesus appears frequently as an object of veneration, esteemed for the ethical values he espoused, and as a model of the spiritual transformation in

${ }^{4}$ Gottfried Korff, "Bemerkungen zum Politischen Heiligenkult im 19. und 20. Jahrhundert", in Gunther Stephenson (ed.), Der Religionswandel unserer Zeit im Spiegel der Religionswissenschaft (Darmstadt, 1976), pp. 216-230.

${ }^{5}$ For example, David Hecht, Russian Radicals Look to America 1825-1894 (Cambridge, MA, 1947), and James H. Billington, Fire in the Mind of Men: Origins of the Revolutionary Faith (New York, 1980). 
humanity that adherence to these values will produce. For example, N. K. Mikhailovskii once claimed that Jesus created the possibility of a new age in history and that through Jesus man could achieve his own salvation. In fact, as Mikhailovskii added on another occasion, "Christianity gave a completely new aspect to history. It brought forth the idea of the absolute worth of man and of the individual." Indeed, N. A. Ishutin had in mind a similar transformation of humanity when he made his celebrated observation that the three greatest men in history were Chernyshevskii, St. Paul, and Jesus Christ. ${ }^{7}$

But it was Jesus's willingness to sacrifice himself for his ideals, as well as these ideals themselves, that made Jesus a paragon of virtue for a movement that elevated self-sacrifice, heroism, and courage to the status of moral principles. Because Jesus's suffering seemed in many ways to resemble their own, many revolutionaries of the nineteenth century retained a love of Jesus long after they had repudiated all remnants of their original Christian faith. Vera Zasulich recounts in her memoirs that as a youth she felt an attraction to "the cause of those who perished", and for that reason continued as an adult to identify with the crucified Jesus. ${ }^{8}$ Vera Figner explains her involvement in revolutionary politics as in large measure the consequence of the belief, which she says she drew from Jesus's life and teachings, that "self-sacrifice is the highest act of which a human being is capable". ${ }^{9}$ The narodovolets, Alexander Mikhailov, writes of how strongly he was impressed by the fortitude and courage of the defendants in the Trial of the Fifty in 1877 , and compares them to the early Christian martyrs, who, he insists, were "teachers of love, equality, and fraternity, the fundamental principles of the Christian commune".${ }^{10}$ Mikhailov's colleague in Narodnaia volia, Andrei Zheliabov, also evoked the image of Jesus, most poignantly at his trial in 1881, which resulted in his execution by hanging:

I deny Orthodoxy, although I affirm the essence of the teachings of Jesus Christ. The essence of his teachings was my primary moral incentive. [. . .]

6 James H. Billington, Mikhailovsky and Russian Populism (New York and Oxford, 1958), p. 131, and Sochineniia N. K. Mikhailovskogo (St. Petersburg, 1896-97), vol. 1, col. 641 .

7 Quoted in "Pokushenie Karakozova", Krasnyi arkhiv, 17 (1926), p. 93.

${ }^{8}$ V. I. Zasulich, Vospominaniia, edited with notes by B. P. Koz'min (Moscow, 1931), pp. 15-16.

9 Vera Figner, Polnoe sobranie sochinenii (Moscow, 1929), vol. 5, pp. 98-99.

${ }^{10}$ Quoted in A. P. Pribyleva-Korba and V. N. Figner, Narodovolets Aleksandr Dmitrievich Mikhailov (Leningrad, 1925), p. 112. Despite what they saw as the decadence and corruption of the Russian Orthodox Church, members of the Chaikovskii Circle referred to the section where defendants sat in the political trials of the 1870's as "Golgotha", the hill near Jerusalem where Jesus was crucified. Sergei Sinegub, Zapiski Chaikovtsa (Moscow-Leningrad, 1929), p. 196. 
All true Christians must fight for truth, for the rights of the humiliated and the weak, and, if necessary, even suffer for them. This is my faith. ${ }^{11}$

Perhaps because Zasulich, Figner, Mikhailov, and Zheliabov disclaimed all the trappings of conventional piety, they could separate Jesus and his disciples from institutional Christianity, lauding the former as ethically pure while condemning the latter as morally bankrupt.

In fact, many Russian revolutionaries of the nineteenth century viewed Jesus not only as a model of moral rectitude but also as an advocate of communal property. Many of the Petrashevtsy, for example, believed that Jesus's agenda included "the realization of freedom and the destruction of private ownership". ${ }^{12}$ To A. A. Komarova, who participated in the bookbinding artels of I. A. Khudiakov in 1864, Jesus was "a great socialist whose teachings had been distorted". ${ }^{13}$ To N. V. Sokolov, a follower of Bakunin and a contributor to Russkoe slovo, Jesus's teachings were "a codex of communism", while the communists' repudiation of private property was "an extension of the teachings of Christ". ${ }^{14}$ In his play, "William Penn", written in 1839 , Alexander Herzen declared that communism was the true ideal of Gospel Christianity. ${ }^{15}$ Finally, Vissarion Belinskii, whose criticisms of Russian Orthodoxy were notable for their rhetorical savagery, confessed nonetheless in a letter to V. P. Botkin in 1840 that liberalism was to a great extent a realization of the ideas of Christ - only to amend his opinion in 1841 by substituting socialism as the secular ideology he thought was implicit in Jesus's teachings. ${ }^{16}$

${ }^{11}$ Quoted in Delo pervogo marta 1881 (St. Petersburg, 1906), pp. 6-7. The celebrated letter that the Executive Committee of Narodnaia volia sent to Alexander III immediately after the assassination of his father contained an appendix in which the authors asserted that " $[t]$ he gallows are as powerless to save the old order [in Russia] as was the death of the Savior on the cross to save the corrupt, ancient world from the triumph of reforming Christianity". (Reprinted in Vera Figner, Memoirs of a Revolutionist (New York, 1968), p. 312.) Like the Narodovol'tsy, Egor Sazanov, the SR assassin of Plehve, claimed he was "continuing the cause of Christ" when he carried out political assassinations. Quoted in Nikolai Valentinov, The Early Years of Lenin (Ann Arbor, MI, 1969), p. 105 .

${ }_{12}$ M. V. Butashevich-Petrashevskii quoted in K. Pazhitov, Razvitie sotsialisticheskikh idei v Rossii ot Pestel'ia do gruppy 'Osvobozhdenie Truda' (Petrograd, 1924), vol. 1, p. 57.

${ }_{13}$ Quoted in E. S. Vilenskaia, Revoliutsionnoe podpol'e v Rossii (60-e gody XIX v.) (Moscow, 1965), p. 333.

${ }^{14}$ Quoted in Feliks Kuznetsov, Publitsisty, 1860-kh godov (Moscow, 1969), p. 281.

${ }_{15}$ A. I. Gertsen, Sobranie sochinenii v tridtsati tomakh (Moscow, 1954-65), vol. 2, p. 304 .

${ }^{16}$ Letter, Belinskii to Botkin (11 December 1840), V. G. Belinskii, Izbrannye pis'ma (Moscow, 1955), pp. 120-121; Letter, Belinskii to Botkin (8 September 1841), Belinskii, Izbrannye pis'ma, p. 173. 
For revolutionaries such as these, Jesus was, in Bakunin's words, "a preacher of the poor, the friend and consoler of the wretched, of the ignorant, of the slaves, and of the women". ${ }^{17}$ Although, in the minds of Jesus's disciples, his teachings would result eventually in the emancipation of all humanity, Russian revolutionaries of the nineteenth century believed he had a particular constituency, the poor and the politically powerless, whose needs and interests he placed above all others. Not surprisingly, Belinskii expressed more eloquently than anyone else of his generation the view of Jesus as a passionate partisan of the impoverished:

The redeemer of mankind came into the world for all men. It was not the wise and educated that he called upon to be "fishers of men" but those who were simple in mind and heart, fishermen; it was not the rich and happy but the poor, the suffering, and the fallen that he sought, some to comfort, others to cheer and restore. [. . .] He, the son of God, loved people with a human love and pitied their poverty and squalor, their shame, wickedness, vices, and sins..$^{18}$

Even the intense, albeit brief, enthusiasm, with which Herzen anticipated the reforms of Alexander II - which he expressed by referring to the new Tsar as "The Galiliean"19 - was animated by the belief that Alexander, like Jesus before him, would lift the peasant masses from their backwardness and squalor.

Of course this image of Jesus is in many ways at variance with what Jesus actually said about property and poverty. Poverty, after all, is one of the monastic vows, and there is a good deal of evidence in the Books of Luke and Matthew that Jesus considered poverty ennobling: "Blessed are you poor. [. . . ] But woe to you that are rich" (Luke 6:20, 24); "Blessed are the

${ }^{17}$ Michael Bakunin, God and the State (New York, 1970), p. 75.

18 V. G. Belinskii, "Vzgliad na Russkuiu literaturu 1847 goda" (1848), reprinted in V. G. Belinskii, Polnoe sobranie sochinenii (Moscow, 1956), vol. 10, p. 301.

${ }^{19}$ A. I. Gertsen, "Ty pobedil', Galileianin'!" (1857), reprinted in Ch. Vetrinskii [V. E. Cheshikhin], Gertsen (St. Peterburg, 1908), pp. 330-333. Interestingly enough, similar views of Jesus can be found in the works of early German and Russian Zionists. For example, Moses Hess remarked that Jesus upheld the idea of universal brotherhood, while Chaim Zhitlovskii considered Jesus a social idealist in the Prophetic tradition. (Moses Hess, Rome and Jenusalem: A Study in Jewish Nationalism, translated by Meyer Waxman (New York, 1945), p. 174; Jonathan Frankel, Prophecy and Politics: Socialism, Nationalism, and the Russian Jews, 1862-1917 (Cambridge, England, 1984), p. 266.) Nachman Syrkin even claimed that Jesus personified "a revolutionary and communist Judaism in Palestine", and that, for Hess, Jesus was nothing less than "a Jewish social revolutionary" (Frankel, Prophecy and Politics, p. 306). This is just one instance demonstrating how readily persons far removed from institutional Christianity could find historical precedent for their particular vision, be it secular or religious, in the life and teachings of Jesus; many other instances can be found in Jaroslav Pelikan's excellent study, Jesus Through The Centuries (New Haven, CT, 1985). 
poor in spirit, for theirs is the kingdom of heaven" (Matt. 5:3); "The kingdom of heaven is at hand [. . .] Take no gold, nor silver, nor copper in your belts" (Matt. 10:7,9). Very different from this was the view of Russian populists like Zheliabov and Figner, who considered poverty a social evil to be abolished once the revolutionary energy it engendered in the peasants had sparked a political revolution. If Jesus seemed to view poverty as a permanent (and laudable) condition, his Russian admirers considered it just a temporary aberration in the evolution of humanity towards a utopia of economic abundance. Notwithstanding the Russian populists, Jesus was never a socialist or an advocate of communal property. Rather, he objected to the acquisitiveness and greed that property, or an excess of property, could sometimes produce. But one searches the Gospel in vain for any explicit declaration that private property per se should be abolished.

With the emergence of Marxism in Russia in the 1890's, the image of Jesus changed. Whereas Russian populists, by and large, had venerated Jesus for his ethics, Russian Marxists - or at least those who considered Jesus a worthy and legitimate antecedent - drew inspiration mostly from his resurrection and divinity. As Marc Raeff has remarked, by the end of the nineteenth century there were no longer many "repentant noblemen" or "repentant revolutionaries" in Russia. ${ }^{20}$ As a result, Jesus would no longer be seen as a kind of revolutionary populist willing to expiate the sins of humanity in the name of universal ethical principles. Instead, under the influence of Marxism, Jesus became a proletarian, or a proto-proletarian, the leader of a movement of the urban poor who, in his resurrection, strongly prefigured the new and immortal Soviet Man that Russian Marxists believed would emerge once the economic preconditions for such a transformation in human nature had been established..$^{21}$ For this reason, both in 1918 after Lenin was wounded and in 1924 after Lenin's death, it was permissible ideologically for many Bolsheviks to equate Lenin and Jesus as revolutionary martyrs who had sacrificed themselves for the masses but who were also superhuman and divine. Although the Bolsheviks always considered Lenin's divinity to be only symbolic, they embellished the cult of Lenin they created with images and symbols strongly suggestive of an analogy between the founder of Bolshevism and the founder of Christianity.

Of course the dominant trend in Russian Marxism and in Bolshevism was towards a revolutionary atheism very similar to that of Marx, whose stric-

${ }^{20}$ Marc Raeff, Understanding Imperial Russia: State and Society in the Old Regime (New York, 1984), pp. 221-222.

${ }^{21}$ For a general description of the New Soviet Man, see Leon Trotsky, Literature and Revolution (Ann Arbor, MI, 1960). Possibly another reason Russian Marxists did not consider Jesus a source of ethical values was that, as Marxists, they believed ethical values were inherent in the dialectical laws of historical development. 
tures on religion were well known. Marx believed that for the exploiting classes religion was an instrument of political repression, while for the exploited classes it was a diversion from revolutionary struggle. Indeed, the very idea of God was logically indefensible and absurd. Equally prominent were Marx's specific criticisms of Christianity, which indicate how little use he had even for its earliest, and presumably its most socially progressive, phase:

The social principles of Christianity justified slavery in antiquity, and they glorified medieval serfdom. [...] The social principles of Christianity preach the necessity of a ruling and an oppressed class [... ] The social principles of Christianity transfer the settlement of all infamies to heaven, and thereby justify the continuation of these infamies on earth. [. . .] So much for the social principles of Christianity. ${ }^{22}$

With the vitriol he seemed to reserve for organized religion, Marx wrote on one occasion that priests are "anointed bloodhounds of the earthly police" and on another that Judaism and Christianity are nothing more than "snakeskins to be shed by history". ${ }^{23}$

The most prominent Russian Marxists reiterated Marx's arguments with a passion he would have admired. To Plekhanov, religion was a travesty of rationality, an intellectual error, and a form of superstition. Jesus Christ, he said, was an "other-worldly" figure who spread the counterrevolutionary message that "slaves [should] submit to God". ${ }^{24}$ According to Trotskii, Jesus "in no way belonged to the Revolution". ${ }^{25}$ According to Lunacharskii, Orthodox Christianity was "an ideology of the oppressed classes" and "a weapon of exploitation". ${ }^{26}$ In Lenin's view, religion was "a kind of spiritual booze or schnapps in which the slaves of capital drown their human image, their demands for a life in some degree worthy of man".${ }^{27}$ Belief in God, he wrote in a 1913 letter to Gor'kii, was a form of "necrophilia" which:

${ }^{22}$ Karl Marx, "Der Kommunismus von der 'Rheinischer Beobachter' ", DeutscheBrüsseler-Zeitung, 73 (2 September 1847), translated and reprinted in Saul K. Padover (ed.), On Religion: The Karl Marx Library (New York, 1974), p. 94.

${ }^{23}$ Karl Marx, The Eighteenth Brumaire of Louis Bonaparte (New York, 1968), (originally published in 1852), pp. 129-130, “Zur Judenfrage”, Deutsch-Französische Jahrbücher (1844), translated and reprinted in Padover, On Religion, p. 170.

${ }_{24}^{4}$ G. V. Plekhanov, Sochineniia (Moscow, 1923-27), vol. 17, p. 265.

${ }^{25}$ Trotsky, Literature and Revolution, p. 121.

${ }^{26}$ A. V. Lunacharskii, Vozrozhdenie pravoslavnoi tserkvi", Vpered, 16 (30 April 1905), reprinted in A. V. Lunacharskii, Pochemu nel'zia verit' v boga? (Moscow, 1965), p. 191. 27 V. I. Lenin, "Sotsializm i religiia", Novaia zhizn', 28 (3 December 1905), reprinted in V. I. Lenin, Sochineniia, 4th edition (Moscow-Leningrad, 1941-50), vol. 10, p. 66. 
always put to sleep and blunted the "social feelings", replacing the living by the dead, being always the ideas of slavery (the worst, hopeless slavery). Never has the idea of God "linked the individual with society": it has always tied the oppressed classes hand and foot with faith in the divinity of the oppressors. $^{28}$

As for Jesus himself, Lenin warned against "the fool in Christ, who harmed the revolutionary movement by his weak-minded preaching of non-resistance". ${ }^{29}$

Not surprisingly, upon taking power in 1917, the Bolsheviks did their best to extirpate Christianity in Russia, viewing it as a historical anachronism without a social base. Both coercive and persuasive measures were taken not only to eliminate the practice of Christianity but to express the Bolsheviks' contempt for its ritual, such as removing the bodies of saints from their tombs and exhibiting them next to the preserved remains of animals and criminals. ${ }^{30}$ Although, as Richard Stites has pointed out, there was a larger nihilistic and iconoclastic trend in Bolshevism that held everything in the past in contempt ${ }^{31}$ many Bolsheviks seemed to reserve a special scorn for Christianity. It took some time before the Bolsheviks grudgingly recognized the need for "red substitutes" (such as baptisms using names drawn from revolutionary mythology) to replace the Christian rituals that they had been trying, without success, to eradicate. ${ }^{32}$ Although the Bolsheviks, under Stalin, would eventually reconcile themselves to the continued practice of Christianity, they would do so with considerable reluctance, and never quite lose the animus towards institutional Christianity that they had inherited from Lenin and, ultimately, from Marx.

But there was another strain in Russian Marxism and in Bolshevism, often minimized or ignored by historians, that viewed Jesus and Gospel Christianity in a more favorable light. It, too, can trace its roots to European socialism. Many European socialists and communists considered Jesus a legitimate and venerable antecedent. Robert Owen openly identified with him, while Babeuf composed a biography in which he described the founder

${ }^{28}$ Letter, Lenin to Gor'kii (November 1913), V. I. Lenin, Sochineniia, 4th edition, (Moscow-Leningrad, 1941-50), vol. 35, p. 90.

${ }^{29}$ Quoted in René Fülöp-Miller, The Mind and Face of Bolshevism (New York, 1962), p. 298.

${ }^{30}$ Ibid., pp. 186-187; David Powell, Antireligious Propaganda in the Soviet Union: A Study of Mass Persuasion (Cambridge, MA, 1975), pp. 23-37.

${ }^{31}$ Richard Stites, "Iconoclastic Currents in the Russian Revolution", in Abbott Gleason, Peter Kenez, and Richard Stites (eds), Bolshevik Culture: Experiment and Order in the Russian Revolution (Bloomington, 1985), p. 8. The Protekul't was an obvious expression of this trend.

32 Fülöp-Miller, Mind and Face, pp. 193-194. 
of Christianity essentially as a sans-culotte. ${ }^{33}$ In the 1820 's, the Italian Carboneri practiced initiation rites in which those seeking membership had to wear a crown of thorns and undergo a mock crucifixion and stigmatization; in their view, Jesus had been an ardent revolutionary fully committed to resisting all authority. ${ }^{34}$ Similarly, many French socialists of the 1830's and 1840's, including Cabet, Leroux, Blanc, and Considérant, saw socialism as the realization of the original promise in Gospel Christianity of a society based on universal brotherhood. ${ }^{35}$ Also in the 1840 's, the first journal in France actually published by workers, L'Atelier, had on its masthead an engraving of Jesus wearing a ribbon bearing the word "fraternité", with two angels, one on each side of him, wearing phrygian caps labelled "égalité" and "liberté". ${ }^{36}$ Finally, it should be mentioned that Proudhon considered Jesus a genius "without equal", and claimed that, in seeking "the regeneration of mankind", he, Proudhon, was continuing what Jesus had begun. ${ }^{37}$

To be sure, the Bolsheviks were far removed - geographically, temporally, and by deliberate choice - from the ideas and traditions of early French socialism. ${ }^{38}$ But until the outbreak of World War I, they held the German socialists in high esteem, and thus were well aware of what the most prominent of them had written on the subject of Gospel Christianity. For example, Rosa Luxemburg claimed that Christianity originally had been a morally pure and politically egalitarian movement, which only later came to betray its own objectives. ${ }^{39}$ Karl Kautsky even devoted an entire book to the thesis that Christianity began as a proletarian, or protoproletarian, revolution against the slave economy of Rome. ${ }^{40}$ In fact, for all of Marx's vituperation and hostility to Christianity, Engels retained throughout his life an ambivalence towards Christianity that enabled him both to distinguish early Christianity from its subsequent incarnations and to praise the former as a forerunner of socialism while attacking the latter as

${ }^{33}$ Frank E. Manuel and Fritzie P. Manuel, Utopian Thought in the Western World (Cambridge, MA, 1979), p. 583, and Billington, Fire in the Minds of Men, p. 76.

${ }^{34}$ Billington, Fire in the Minds, p. 131.

${ }^{35}$ Edward Berenson, Populist Religion and Left-Wing Politics in France, 1830-1852 (Princeton, NJ, 1984), pp. 36-73.

${ }^{36}$ Billington, Fire in the Minds, p. 257.

${ }^{37}$ Quoted in Henri de Lubac, The Un-Marxian Socialist: A Study of Proudhon, translated by R. E. Scatlebury (London, 1948), p. 65.

${ }_{38}$ They were also well aware of Marx's contempt for Proudhon, which he expressed in his pamphlet, Misère de la Philosophie: Response à la Philosophie de M. Proudhon (Paris and Brussels, 1847).

${ }^{39}$ Peter Nettl, Rosa Luxemburg (Oxford, 1969), p. 221.

${ }^{40}$ Karl Kautsky, Der Ursprung des Christentums: eine historische Untersuchung (Stuttgart, 1908). 
analogous in several ways to capitalism. His position is expressed most clearly in his essay, "On the History of Early Christianity":

The history of early Christianity has notable points of resemblance with the modern working-class movement. Like the latter, Christianity was originally a movement of oppressed people: it first appeared as the religion of slaves and emancipated slaves, of poor people deprived of all rights, of peoples subjugated or dispersed by Rome. Both Christianity and the workers' socialism preach forthcoming salvation from bondage and misery; Christianity places this salvation in a life beyond, after death, in heaven; socialism places it in this world, in a transformation of society. Both are persecuted and baited, their adherents are despised and made the objects of exclusive laws, the former as enemies of the human race, the latter as enemies of the state, enemies of religion, the family, social order. And in spite of all persecution, nay, even spurred on by it, they forge victoriously, irresistibly ahead. $^{41}$

Although Engels subsequently denies the significance of Jesus, the man neither Christianity nor socialism, he says, was created by "leaders and prophets" 42 - his writings on Christianity nonetheless established a framework for the qualified praise of Jesus and Gospel Christianity that several Bolsheviks would subsequently express. ${ }^{43}$

In Bolshevik writings one finds numerous favorable references to Jesus, some of them quite complimentary, almost all of them consistent with the view of Engels and Kautsky that, in its ideas and social origins, Gospel Christianity was much like socialism and communism. For example, in 1918 Bogdanov asserted that "Christ, if he existed, was undoubtedly a proletarian" and that Christianity, at its inception, was a politically progressive and revolutionary movement. ${ }^{44}$ Similar statements can be found in the writings of other Bolsheviks and Bolshevik sympathizers such as Gor'kii, Maiakovskii, and Bednyi. ${ }^{45}$ But undoubtedly the fullest, most scholarly, and most

${ }^{41}$ Friedrich Engels, "Zur Geschichte des Urchristentums", Die Neue Zeit, vol. 13 (1894-95), translated and reprinted in Karl Marx and Friedrich Engels, Basic Writings on Politics and Philosophy, edited by Lewis S. Feuer (Garden City, New York, 1959), p. 168.

${ }^{42}$ Ibid., p. 180.

${ }^{43}$ And also such communists as Fidel Castro, who once declared that Marx "could have subscribed to the Sermon on the Mount" and that the struggle of the Cuban communists against Batista was comparable to that of the early Christians against the Roman Empire. Fidel and Religion: Castro Talks on Revolution and Religion with Frei Betto (New York, 1987), pp. 271, 273.

44 A. Bogdanov, Nauka i rabochii klass (Moscow, 1918), p. 15.

${ }^{45}$ Even as strenuous a critic of Bolshevism as Berdiaev maintained that the Gospel rejected private property and that John Chrysostom was "a complete communist". Nicolas Berdayev, The Origin of Russian Communism (Ann Arbor, MI, 1960), p. 160. 
systematic treatment of Jesus and Gospel Christianity is in the writings and lectures of Anatolii Lunacharskii, the first Commissar of Education in the Soviet Union. ${ }^{46}$ For this reason it seems worthwhile to examine Lunacharskii's views in some detail.

On every occasion when Lunacharskii undertook to explain the origins of Christianity, he claimed that it originated as a proletarian, socialist, democratic, and revolutionary movement. In 1908, in the second volume of a two-volume study of Christianity, Lunacharskii wrote that Christianity had emerged from the same milieu, and for the very same reasons, as did several messianic movements containing elements of Judaism and "Greco-Asiatic" culture.$^{47}$ One of these was the Essene, which included people who, in their hatred of wealth and power and their "profound democratic ways", practiced a form of "monastic communism". ${ }^{48}$ In much the same way, Christianity was originally "an ideology of poverty" that gained support from persons of the lower classes who were "permeated by a spirit of collectivism" and who therefore shared what little property they had. ${ }^{49}$ In fact, Gospel Christianity and Marxism are similar in that "their ideals are partly congruent". ${ }^{50}$ With the bravado and confidence that characterizes the tone of his work, Lunacharskii fleshed out what he saw as the radicalism of Gospel Christianity:

The communist spirit of early, popular Christianity is not in doubt. But was it revolutionary? Of course it was. In its negation of the cultural world of the time - radical, merciless negation - and in its posing in its place a completely new way of life, it was revolutionary. Any ideology which truly mirrors the mood of the oppressed masses cannot not be revolutionary. ${ }^{51}$

In subsequent works that dealt with Christianity, Lunacharskii never deviated from what he had written in 1908. In a series of lectures delivered in Moscow in 1918 (and subsequently published as a pamphlet in 1923), Lunacharskii again proclaimed that Christianity had begun as a democratic and socialist movement and that it "developed mainly among the proletarians". ${ }^{52}$ In 1922, in an essay on the history of Christianity, Lunacharskii

${ }^{46}$ There is no full-length biography of Lunacharskii in English. However, his early years are treated in A. L. Tait, Lunacharsky: Poet of the Revolution (1875-1907) (Manchester, 1984), and his activities as Commissar are discussed in detail in Sheila Fitzpatrick, The Commissariat of Enlightenment: Soviet Organization of Education and the Arts under Lunacharsky, October 1917-21 (Cambridge, England, 1970).

${ }^{47}$ A. V. Lunacharskii, Religiia $i$ sotsializm (St. Petersburg, 1911), vol. 2, p. 8.

${ }^{48}$ Ibid., p. 11.

49 Ibid., p. 62, 101.

so Ibid., p. 159.

s1 Ibid., p. 139.

${ }^{52}$ A. V. Lunacharskii, Vvedenie $v$ istoriiu religii (Moscow, 1923), reprinted in A. V. 
claimed that "the first Christian communities both in Palestine and in the big cities [in the Near East] were associated with powerless proletarians, slaves, petty artisans - in sum, the poor". ${ }^{53}$ In a speech delivered in 1923 in the Zimin Theater in Moscow, Lunacharskii argued that Christianity:

was at first really the religion of slaves, of the downtrodden, of the poor, who were coming gradually to the position of conscious protest against the religion of the wealthy. As the basis of this kind of democratic religion there was, of course, the ideas of democracy, revolution, and even, sometimes to a significant degree, socialism. ${ }^{54}$

Three years later, Lunacharskii again argued that Gospel Christianity and communism both repudiate the principle of private property and that, "as social tendencies [they] coincide on several historical points". ${ }^{55}$ Although, in his 1918 lecture, Lunacharskii defined the term "proletariat" somewhat idiosyncratically to mean all those who lived in cities but who worked on the land without owning it - rather than an industrial working class ${ }^{56}$ he usually ignored his own definition and classified all of the earliest Christians as proletarians in order to reinforce the analogy that he saw between communism and Gospel Christianity.

In Lunacharskii's view, however, Christianity very quickly lost its progressive and positive character. Given the circumstances under which it arose, this could not have been otherwise. In all of his writings on Christianity, Lunacharskii maintained (at times with a trace of regret) that Gospel Christianity could not have served as a vehicle for an actual lower-class revolution. Because the objective conditions for such a revolution were entirely absent, and because the social classes from which it drew its first adherents were insufficiently powerful, Christianity eventually was captured by other classes less dissatisfied with their place in society. In turn, these classes altered Christian theology to reflect their political passivity. For Lunacharskii, the principal catalyst for this transformation was Paul, whom he described succinctly, if unfairly, as a "social opportunist". ${ }^{57} \mathrm{By}$ emphasizing man's original sin, which could only be atoned for through individual actions on earth, Paul made Christianity attractive to the meshchantsvo (or petite bourgeoisie) of his day, who helped to dilute, and

Lunacharskii ob ateizme i religii (Moscow, 1972), p. 174.

${ }^{53}$ A. V. Lunacharskii, Komu prinadlezhit tserkovnoe imushchestvo? (Moscow, 1922), reprinted in Lunacharskii, Pochemu nel'zia verit'?, p. 201.

${ }_{54}$ A. V. Lunacharskii, "Idealizm i materializm", (1923) reprinted in A. V. Lunacharskii, p. 28.

55 A. V. Lunacharskii, Khristianstvo ili kommunizm (Leningrad, 1926), reprinted in Lunacharskii, Pochemu nel'zia verit'?, p. 67.

${ }_{56}$ Lunacharskii, Vvedenie $v$ istoriiu religii, reprinted in $A . V$. Lunacharskii, p. 184.

57 Lunacharskii, Religiia $i$ sotsializm, vol. 2, p. 71. 
eventually to eliminate, the democratic and proletarian aspect of Gospel Christianity. ${ }^{58}$

And so, in Lunacharskii's account of it, there were for many years two competing tendencies in Christianity, a proletarian one and a petit-bourgeois one. Luke and, later on, the millenarian sects were the principal advocates of the former, while Paul and, later on, the Gnostics were the principal advocates of the latter. ${ }^{59}$ As a result, Christian theology - to the extent that it was a coherent and unitary body of dogma - underwent several changes in emphasis and even in substance. In the hands of Paul, salvation became a matter of faith rather than of revolt. The political revolution that the original Christian proletariat had believed to be imminent would have to be postponed until the Second Coming of Christ, and there was nothing Christians could do to accelerate the Second Coming except to sustain their faith through prayer and the quiet endurance of adversity. What this meant in practical terms, according to Lunacharskii, was an acceptance of the political status quo. Even the promise of a second coming of Christ (who was still viewed by Paul and his followers as a catalyst of radical change) served to dampen revolutionary energy, for the very notion of a second coming - what Lunacharskii on one occasion referred to as "foreign intervention" 60 - seemed to make God, not man, the agent of man's liberation.

The ultimate result, according to Lunacharskii, was that Christianity became an instrument of the upper classes for exploiting the poor, with the Church mobilizing its formidable resources to suppress the various egalitarian heresies that attempted to perpetuate the original message of Christianity. As much as Lunacharskii sympathized with these heresies, he recognized that the external conditions for their success did not exist. There was no way, given the stage of history at which all of this occurred, that these heresies, or Gospel Christianity itself, could have survived. Indeed, as Lunacharskii claimed in several places, Christianity, for all its original promise, has been a failure: fully 1900 years have passed since Christianity arose, and the amount of injustice in the world has not appreciably diminished. ${ }^{61}$ As he argued in his 1923 speech, Christianity was a democratic movement only briefly, its "revolutionary idealism" very quickly dissipating into "deception and self-deception". ${ }^{62}$ The problem, as Lunacharskii

${ }^{58}$ Ibid., pp. 58-60.

s9 Ibid., pp. 53-101.

${ }^{60}$ Lunacharskii, Khristianstvo ili kommunizm, reprinted in Lunacharskii, Pochemu nel'zia verit'?, p. 75.

61 See, for example, A. V. Lunacharskii, "Lichnost' Khrista v sovremennoi nauke i literature (Ob 'Iisuse' Anri Barbiusa)", (3 October 1927), reprinted in A. V. Lunacharskii, p. 252.

${ }^{62}$ Lunacharskii, "Idealizm i materializm", reprinted in A. V. Lunacharskii, p. 35. 
defined it, was that, for all its similarities to socialism and communism, Gospel Christianity was unable to recognize the material nature of reality:

For social democracy [the Bolsheviks], the revolution is not an apocalyptic event, an intervention of spirit, which, whatever its moral imperative, energizes the will of people. [. . . ] It is not an act of spirit which changes the material process; this is only a form, one of the many forms that socialeconomic progress can take. ${ }^{63}$

According to Lunacharskii, this is why Christianity failed, and it is also why Bolshevism, based as it is on dialectical materialism, cannot fail.

Where, in all of this, was Jesus himself? What role, if any, did he play in the tragic saga of Christianity that Lunacharskii related with such eloquence and ideological conviction? In this regard Lunacharskii changed his views. In 1908 he acknowledged that Jesus had once existed, and characterized the story of his life as "a mixture of legend and fact", its supernatural and mystical aspects - the miracles, virgin birth, and resurrection - largely a consequence of the masses' need for a savior who would eradicate injustice and eliminate oppression. ${ }^{64}$ Having said this, Lunacharskii could then ascribe to Jesus a pivotal role, as the leader of the earliest Christians, in the genesis of their revolutionary consciousness. At one point Lunacharskii even rebuked Nietzsche for claiming that Jesus espoused a "morality of slavery"; there is not, he said, "a shadow of truth" in this, for Jesus expressed a passion and an indignation at the existence of oppression that made him, in the eyes of the lower classes, "the model of an avenger, a judge, and a founder of life [. . .] the model of blissfulness in chiliastic force, the model of earthly life in his love, patience, and communism". ${ }^{65}$ But there were also limits to Jesus's radicalism, and a potentially harmful dualism in Jesus's message:

Christ had two faces. As a communist, as a teacher of humble wisdom, of living happily for God, with direct faith in the existence of the highest form of goodness, which leads everyone to good deeds, he was a model of meekness and forgiveness. As one who unmasked the existing governmental order, as one who made a spirit of revenge boil up in the masses, he terrified the world and made it more somber. He was a great scold, ready to set the whip in motion, although the threat of it was a sufficiently cruel fantasy. ${ }^{66}$

In turn, Lunacharskii continued, this dualism provided theological ammunition for the petit-bourgeois trend that emerged in Christianity after the

${ }^{63}$ Lunacharskii, Religiia i sotzializm, vol. 2, p. 163.

${ }^{64}$ Ibid., p. 22.

${ }_{65}$ Ibid., p. 16.

${ }^{66}$ Ibid., pp. 139-140. 
crucifixion. The "meekness" and "forgiveness" Jesus embodied became a justification and a model of the acceptance of exploitation and repression. In fact, as first the petite bourgeoisie and then the upper classes transformed Christianity into an instrument for perpetuating their economic interests, Jesus himself underwent a metamorphosis:

From the Christ with pierced feet, hands, and flanks, from the Christ on the gallows, from the Christ in rags [. . .] was made the son of the tsar of the heavens, the original heavenly crown prince, with a glittering diamond crown, with eyes so full of wisdom one had to fall on one's knees before him, just as one does for the tsarevich. ${ }^{67}$

Nevertheless, as Lunacharskii reiterated in an essay composed in 1909, Jesus existed, and no amount of obfuscation by those who betrayed the original message of Christianity could deny that Jesus had been a revolutionary and a communist, "a unique leader of the proletarian masses of Galilee, a proletarian hero, a teacher of great love and also of great hatred". 68

From 1908 to 1927, Lunacharskii's view of Jesus - of his existence and of his message - did not change. At any rate there is nothing in his published work to indicate that it did. But in notes he wrote in preparation for a public debate in 1927 with the prelate and Christian socialist, Alexander Vvedenskii, on the origin and development of Christianity, he revealed a skepticism generally absent from his earlier writings. In the notes, in the context of criticizing a recent biography of Jesus by the French writer, Henri Barbusse, Lunacharskii wrote the following:

Barbusse with such love nowadays glorifies the proletarian revolution, he understands - he says - its ideas and meaning so well, that it becomes strange that he should waste his time on the dubious satisfaction of digging up, in essence of cooking up, a certain Jesus, a man who scarcely existed, who didn't leave about his existence any kind of clear trace, and of delivering this unknown corpse from his present exploiters, trying to make him his ally. ${ }^{69}$

In the debate, Lunacharskii dismissed the story of Jesus as "the purest myth", ${ }^{70}$ and as the product of a collective imagination. In this new formulation, Jesus was, at the very most, a composite of several persons, reflecting the need among the earliest Christians for a synthetic figure who could bind

${ }^{67}$ Lunacharskii, "Idealizm i materializm", reprinted in $A$. V. Lunacharskii, p. 34.

${ }^{68}$ A. V. Lunacharskii, "T'ma" (1909), reprinted in Literaturnyi raspad (St. Petersburg, 1909), vol. 1, p. 155.

${ }_{69}$ A. V. Lunacharskii, "Materialy k dokladu 'Lichnost' Khrista' " (1927), reprinted in Lunacharskii, Pochemu nel'zia verit'?, p. 20.

${ }^{70}$ A. V. Lunacharskii, "Lichnost Khrista", reprinted in A. V. Lunacharskii, p. 233. 
their movement together. However, a more reasonable conclusion was that the Jesus story was a complete fabrication - a conclusion that Lunacharskii supported by referring to various contradictions, omissions, and falsehoods that he claimed to find in the Gospel itself. ${ }^{71}$

In this way, Lunacharskii seemed to qualify rather severely the veneration of Jesus and the centrality of his role in Christianity that one finds expressed in the writings of Russian populists and other revolutionaries of the nineteenth century. But however much Lunacharskii may have minimized Jesus's importance - even to the point, in 1927, of denying his existence - he nevertheless continued the analogy the populists had posited between Gospel Christianity and Russian radicalism. ${ }^{72}$ What had changed, in addition to the role of Jesus, were the terms of the analogy: the populists had viewed the earliest Christians essentially as peasants, while Lunacharskii considered them primarily to have been proletarians. But the analogy itself survived.

The analogy was strengthened when many of those who supported the October Revolution (and some who did not) explained the Revolution in Christian terms, principally as a spiritual resurrection and rebirth. Dem'ian Bednyi, who was sometimes called the "poet-laureate" of Bolshevism, composed a poem, "To the Leader", published in Pravda in 1918, in which he called Lenin's writings "the Holy Bible of Labor", and castigated Lenin's enemies as "Judases". ${ }^{73}$ Several of the leading Bolsheviks were among his friends. Similarly, Maiakovskii often identified the October Revolution with the Second Coming of Christ. For example, at the end of 1917 he wrote a play, Mystery-Bouffe, in which the earth is destroyed in a flood and a poet arrives on Noah's Ark to deliver a new Sermon on the Mount - which Maiakovskii intended as an analogy to the October Revolution..$^{74}$ Also in 1917, Sergei Esenin composed a poem, "Comrade", in which a revolutionary Christ hears the pleas of workers singing the "Marseil-

${ }^{71}$ Ibid., pp. 229-253.

${ }^{72}$ For example, V. V. Bervi-Flerovskii, who composed a manifesto for one of the populist groups that "went to the people", in 1874 , filled the manifesto with quotations from the Gospel because he believed political agitation among the peasants could be successful only if it were presented as part of an effort to create a new "religion of equality" similar to Gospel Christianity. According to Bervi-Flerovskii, the early Christians had such an abundance of enthusiasm, courage, and moral vision that any contemporary radical group choosing to emulate them would be guaranteed the same success they enjoyed. And should the revolutionary movement in Russia sincerely profess the ethos of equality Bervi-Flerovskii claimed was implicit in Gospel Christianity, the two movements, in their totality, would be analogous. N. Flerovskii, Tri politicheskie sistemy (London, 1897), pp. 297-298.

73 Dem'ian Bednyi, "Vozhdiu", Pravda, 87 (4 May 1918), p. 3.

${ }^{74}$ Robert C. Williams, Artists in Revolution: Portraits of the Russian Avant-Garde, 1905-1925 (Bloomington, 1977), p. 138. 
laise", descends from the cross, and dies in their midst. ${ }^{75}$ Even Alexander Vvedenskii, Lunacharskii's future opponent in debate, insisted in the early 1920 's that Marxism was just "the Gospel reset in atheist type", and that "while the Marxists, Communists, and Soviet authorities do not follow Christ, they work to fulfill Christ's precepts". ${ }^{76}$

As for Andrei Belyi, who was often mistakenly considered a supporter of the October Revolution, several of his works put forth an image of the Revolution as a harbinger of the Second Coming of Christ. In his 1918 poem, "Christ is Risen", Belyi portrayed the death of Jesus in the context of a Russian nation that has lost its moral righteousness. Possibly in contradiction of what the poet intended, many who read the poem construed the October Revolution to be the historical equivalent of Jesus's resurrection. ${ }^{77}$ Whatever the accuracy of such an equivalence, Belyi also composed a poem, "To the Motherland", in which he explicitly equated Russia and Christ, and called his native land "the Messiah of the coming age". ${ }^{78}$ As for Alexander Blok, it seems that, regardless of his unresolved ambivalence towards the Bolsheviks, his celebrated poem, "The Twelve", was often read as an extended analogy between the Bolsheviks and the twelve apostles of Christ. In the poem, Christ is leading a Bolshevik detachment of soldiers, twelve in number, who, without knowing it, are doing Christ's work. Finally, as the soldiers trudge through the snow:

In a chaplet of white roses

Stepping through the pearly snowdrift

Shrouded in the snowy mist

In the distance - Jesus Christ ${ }^{79}$

After the poem was published, Blok said that he had changed his mind and no longer liked the ending he had written. But he never managed to write another one. ${ }^{80}$

75 Sergei Esenin, “Tovarishch”, reprinted in Skify (Petrograd, 1917), vol. 2, pp. 264 268. Like Maiakovskii, Esenin would eventually commit suicide in despair over what he viewed as the moral degeneration of Bolshevism.

${ }^{76}$ Quoted in Lunacharskii, Khristianstvo ili kommunizm, reprinted in Lunacharskii, Pochemu nel'zia verit'?, p. 27; quoted in A. A. Shishkin, Sushchnost' i kriticheskaia otsenka 'obnovlencheskogo' raskola v russkoi pravoslavnoi tserkvi (Kazan, 1970), p. 121. $n$ Andrei Belyi, "Khristos voskrese", reprinted in Andrei Belyi, Stikhotvoreniia (Berlin, 1923), pp. 347-371, and G. S. Smith, "Bely's Poetry and Verse Theory", in John E. Marshall (ed.), Andrey Bely: Spirit of Symbolism (Ithaca, NY, 1987), pp. 270-273.

${ }_{78}$ Andrei Belyi, "Rodine", reprinted in Skify, Sbornik 2-i (Petrograd, 1918), vol. 2, p. 36.

${ }_{79}$ Aleksandr Blok, Dvenadtsat' (Petrograd, 1918), p. 62.

${ }^{80}$ Helen Muchnic, From Gorky to Pasternak: Six Writers in Soviet Russia (New York, 1961), p. 169. 
Blok's ambivalence was shared by Maxim Gor'kii. After the October Revolution, Gor'kii left Russia and did not return until 1928. A friend of Lenin, he may eventually have been murdered by Stalin. But through the vicissitudes of his relations with the Bolsheviks, he never lost his vision of a socialist society grounded in the ethics of Jesus. In his famous novel, Mother, Gor'kii depicted the gradual politicization and radicalism of a mother, one of whose sons has joined a revolutionary circle. At first, the mother objects, but slowly she comes to recognize the superior virtue of his cause:

Our own children, blood of our blood, have gone forth into the world in the name of justice for all! They have taken up this cross in search of a brighter day for all of you, and for your children. It's another life they want - a life of truth and justice. It's goodness they want, for all people. [. . .] Our children have gone forth into the world to seek joy, and they have done it for all our sakes and for the sake of Christ's truth. [. . .] There would have been no Lord Jesus if people had not given their lives to bring Him glory. ${ }^{81}$

Indeed, the image of self-sacrifice, inspired by the memory of Jesus's martyrdom, was a frequent one in the writings of Bolsheviks and Bolshevik supporters. Also in Gor'kii's novel, one of the characters, Rybin, seems to be speaking for the author when he proclaims: "Let thousands of us die to resurrect millions of people all over the earth! That's what! Dying's easy for the sake of the resurrection! If only the people rise!" 82 In the 1920's, Sergei Eisenstein depicted death in several of his films as an act of revolutionary martyrdom, most poignantly, perhaps, in "Potemkin". ${ }^{83}$ So as to avoid the impression that only such Bolshevik "fellow-travelers", and not the Bolsheviks themselves, believed that martyrdom was morally ennobling and conducive to a revolutionary transformation of society, one need only cite the words of Lunacharskii that "the future collectivist culture will teach the masses to die for the common good, [ . . .] to sacrifice [itself] to realize the conception of socialism". ${ }^{84}$

Given the emphasis in Orthodox Christianity on the resurrection rather

${ }^{81}$ Maksim Gor'kii, Mat' (Moscow, 1977), p. 146.

${ }^{82}$ Ibid., p. 123.

${ }^{83}$ Williams, Artists in Revolution, pp. 20-23.

${ }^{84}$ Lunacharskii, Religiia $i$ sotsializm, vol. 2, p. 385. The Jesus analogy is even used, albeit rarely, in Soviet politics today. At a meeting of the Moscow Communist Party in October 1987, at which Boris El'tsin was sharply criticized for what his rivals considered his overly strident advocacy of glasnost', he was rebuked by V. A. Zharov, the deputy chairman of the Moscow City Council. Zharow complained, inter alia, that "we will see people who will try to make Boris Nikolaevich [El'tsin] into a Jesus Christ who suffered for his fervently revolutionary devotion to social revitalization and democracy", Pravda (13 November 1987), p. 2. In this instance Zharov seems to be speaking ironically and sarcastically, though it is interesting that he believes there are "people" in the Soviet 
than the birth of Christ (so that Easter, not Christmas, is the principal Christian holiday in Russia), it is not at all surprising that the October Revolution, with its apocalyptic and universalist overtones, should have been perceived, even by some of the Bolsheviks themselves, as a resurrection, a rebirth, and a harbinger of a second coming of Christ. But there is an additional dimension to the Bolsheviks' veneration of Jesus, and to their use of him as a political and ideological antecedent. This was their recognition of Jesus's physical resurrection - something on which the populists and the other revolutionaries of the nineteenth century had been almost entirely silent ${ }^{85}$ In creating a New Soviet Man, whose life could be extended indefinitely, the Bolsheviks hoped to use not only scientific and medical technology but also the historical precedent of Jesus, who, by his resurrection, proved that the existing scientific maxims about the permanence of death were not as impervious to alteration as nearly everyone believed. In the Bolshevik view, Jesus was not only a proletarian and a revolutionary martyr, he was also capable of physical resurrection. And because of this, he would be a suitable antecedent of the New Soviet Man once the Bolsheviks separated him from the institutional Christianity that they believed had besmirched and perverted his original message. As a martyr, Jesus could comfort the Bolsheviks when their leaders died, but his resurrection augured the day when these leaders could be revived and when everyone in a socialist society would enjoy eternal life. Of course there is a great deal of difference between resurrection through faith and resurrection through science: if the former is in its origins a Christian concept, the latter stems from the Promethean tradition of scientism and positivism in European thought in the nineteenth century, from which the Bolsheviks drew much of their revolutionary enthusiasm. But it was through their evocation of Jesus that the Bolsheviks were able to synthesize these two traditions and to make a part of their revolutionary mythology a figure whose religious faith and resurrection served to strengthen the Bolsheviks' confidence in overcoming adversity and eventually constructing a secular utopia.

There were many in Russia outside the revolutionary movement who, in the half-century before the October Revolution, speculated on the possibility of resurrection and immortality. Directly and indirectly, some of them influenced the Bolsheviks. Certainly the most significant of these persons was N. F. Fedorov, the librarian at the Rumiantsev Museum in Moscow, who, without ever writing a book, attracted the attention of several Bolshe-

Union who will use an analogy with Jesus to express their support of El'tsin and glasnost'. ${ }_{85}$ It is true that in the 1870 's Nikolai Chaikovskii spoke of creating "God-men" who would combine the finest attributes of Jesus and humanity. But the attribute of Jesus that Chaikovskii prized most highly was his moral purity, not his divinity or capacity for resurrection. M. Frolenko, "Chaikovskii. Ego bogochelovechestvo", Katorga i ssylka, 26 (1926), pp. 217-223. 
viks, including Bogdanov, Lunacharskii, and Leonid Krasin. ${ }^{86}$ Fedorov formulated the idea that, through the application of science and technology, the living could resurrect the dead and give them perpetual life. In fact, Fedorov believed that the resurrection of past generations was the highest obligation of humanity and the best expression of a synthesis of science and Christianity. ${ }^{87}$

At roughly the same time as Fedorov, several others postulated similar ideas. A Nobel Prize winner in 1908, Il'ia Mechnikov expressed the view that "death is not necessarily inherent in living organisms" ${ }^{88}$ Although Mechnikov spent most of his adult life in Paris, his ideas achieved some notoriety in Russia where he influenced a number of Bolsheviks and Bolshevik sympathizers, including Mel'nikov, the architect of Lenin's sarcophagus. ${ }^{89}$ In much the same way as Mechnikov, N. A. Rozhkov and S. N. Metalnikov (the latter a pupil of Mechnikov) tried to disseminate their belief that "immortality is the fundamental property of living organisms". 90 Several others, such as Sergei Voronov, proposed that humanity should strive for perpetual youth. ${ }^{91}$ Vladimir Vernadskii, who for many years directed a Commission for the Study of the Natural Productive Forces in Russia, postulated the existence in the universe of a "biosphere", where dead organisms could be revived through the injection of living matter. ${ }^{92}$ Pavel Bakhmetov, a physicist, actually attempted in his laboratory to restore life to dead animals by placing them in an extremely cold envi-

${ }^{86}$ Nina Tumarkin, "Religion, Bolshevism, and the Origins of the Lenin Cult", Russian Review, 40 (January 1981), no. 1, p. 44, and S. V. Utechin, "Bolsheviks and their Allies After 1917: The Ideological Pattern", Soviet Studies, 10 (October 1958), no. 2, pp. 129-130. Immediately after Lenin's death, Krasin oversaw the embalming of Lenin's body and the construction of a temporary mausoleum. A few months later, Lunacharskii assumed leadership of the commission in charge of designing a permanent mausoleum. The roles of both men in these events reflected Fedorov's influence, particularly in the case of Krasin.

${ }^{87}$ Although Fedorov usually expressed his thoughts on unsigned scraps of paper, their authorship was eventually discovered. Many of his writings have been collected in N. F . Fedorov, Filosofiia obshchego dela, edited by V. A. Kozhevnikov and N. P. Peterson. Volume I was published in Alma Ata in 1906, and Volume II in Moscow in 1913. N. F. Fedorov, Sochineniia, edited by S. Semonova (Moscow, 1982), contains selections from these volumes as well as previously unpublished material from the Fedorov Archive. See also Peter Wiles, "On Physical Immortality", Survey, 56 (July 1965), p. 133.

${ }_{88}$ Quoted in Élie Mechnikoff, The Nature of Man: Studies in Optimistic Philosophy (New York, 1910), p. 265.

${ }^{89}$ Wiles, "On Physical Immortality", p. 143-144; S. Frederick Starr, Melnikov: Solo Architect in a Mass Society (Princeton, NJ, 1978), p. 253.

${ }^{9}$ N. A. Rozhkov, Osnovy nauchnoi filosofii (St. Petersburg, 1911); Mechnikov quoted in Wiles, "On Physical Immortality", p. 147.

${ }^{91}$ Wiles, "On Physical Immortality", p. 147. Voronov also lived in France, though his books, like Mechnikov's, were published in Russia.

${ }^{92}$ Utechin, "Bolsheviks and their Allies", pp. 130-131. 
ronment. ${ }^{93}$ Around the turn of the century, philosophers such as Solov'ev and Merezhkovskii expressed a vision of a New Christianity, the adherents of which would presumably possess some of the attributes of Jesus, most notably a spiritual purity (which was stressed by Solov'ev) and a kind of divinity (which was emphasized particularly by Merezhkovskii). ${ }^{94}$

Not surprisingly, several Bolsheviks shared this impulse to deify humanity by attributing to humanity a capacity for immortality and bodily resurrection. Much has been written in this regard about the God Builders Gor'kii, Bogdanov, Lunacharskii, and several others - who infuriated Lenin with their attempts to synthesize Marxism and religion..$^{95}$ Here one need only reiterate that the immortality Lunacharskii imagined would accompany socialism was entirely symbolic and collective; to expect this immortality to be literal and individual was, in Lunacharskii's view, to profess "a peasant belief that should not be taken seriously". ${ }^{96}$

But among the Bolsheviks there was considerable fascination with the resurrection, rejuvenation, and indefinite prolongation of life - which continued to characterize Soviet gerontology long after the October Revolution. Gor'kii, Maiakovskii, and Bogdanov all believed in the possibility of physical immortality, and Bogdanov died in 1928 as the result of a blood transfusion he performed on himself in an experiment in the prolongation of life. ${ }^{97}$ Also in the 1920 's, the prominent Bolshevik historian, Mikhail Pokrovskii, expressed his support of a manifesto printed in Moscow calling upon "everyone without distinction of sex, age, race, class, or faith and world-view to struggle with an enemy [i.e. mortality] that is age-old and mighty but vanquishable". ${ }^{98}$ The manifesto concluded by calling, in capital letters, for the dead of all lands to unite. ${ }^{99}$ With an objective similar to that

${ }^{93}$ Starr, Melnikov, p. 245; for information on Bakhmetov, see "Vselenskoe delo v proshlom", Vselenskoe delo, sbornik (Riga, 1934), vol. 2, pp. 107-111.

${ }_{94}$ Vladimir Solov'ev, Chteniia o bogochelovechestvo, reprinted in Sobranie sochinenii V.S. Solov'eva (St. Petersburg, 1911), pp. 3-181, and Bernice G. Rosenthal, Dmitrii Sergeevich Merezhkovsky and the Silver Age: The Development of a Revolutionary Mentality (The Hague, 1975), p. 91.

${ }^{95}$ See, for example, George Kline, Religious and Anti-Religious Thought in Russia (Chicago, 1968), and Robert C. Williams, The Other Bolsheviks: Lenin and His Critics, 1904-1914 (Bloomington, 1986).

${ }^{96}$ A. V. Lunacharskii, Nauka, iskusstvo, religiia (Moscow, 1923), p. 14.

${ }_{77}$ A. Ostromirov, N. F. Fedorov i sovremennost' (Harbin, 1928), vol. 2, p. 14; Roman Iakobson and D. Sviatopolk-Mirskii, Smert' Maiakovskogo (The Hague, 1975), pp. 25-28, and Tumarkin, "Origins of the Lenin Cult", p. 43. See also Bogdanov's novel, Krasnaia zvezda, which describes how, on Mars, human life expectancy is increased through blood transfusions. Reprinted in English in Alexander Bogdanov, Red Star: The First Bolshevik Utopia, edited by Loren Graham and Richard Stites (Bloomington, 1984).

98 "Vselenskoe delo v proshlom", pp. 113-115.

99 Ibid., p. 184. 
of the manifesto, Olga Lepeshinskaia, who had joined the Party in 1898 and knew Lenin personally, published a number of works on the prolongation of life and also headed the Department of Living Matter in the All-Union Institute of Experimental Medicine. There she tried to develop organic matter from inorganic matter. ${ }^{100}$ The spirit of her endeavor is captured very well in the words of Valerian Murav'ev, a disciple of Fedorov and an official in the Commissariat of Foreign Affairs, who wrote shortly after the October Revolution:

We have passed beyond those periods of human history when it was possible to think only of the psychic alteration of man, of developing in him one or another set of ideas or moral inclinations. Along with this necessary task of perfecting man internally there stands before us the problem of his more thorough transformation and renewal, of the alteration of mankind as a physical type. [. . .] We already have a series of applied sciences that are working out a practical approach to this problem. [. . . In various experiments [in biology] methods are being devised for achieving a victory over death by means of vitalizing and resuscitating body organs. ${ }^{101}$

Finally, in a 1921 speech which Krasin delivered at the funeral of a fellow Bolshevik, L. Ia. Karpov, he prefigured the sentiments which would cause him to advocate the mummification of Lenin's body in 1924:

I am certain that the time will come when science will become all-powerful, that it will be able to recreate a deceased organism. I am certain that the time will come when one will be able to use the elements of a person's life to recreate the physical person. And I am certain that when that time will come, when the liberation of mankind, using all the might of science and technology, the strength and capacity of which we cannot now imagine, will be able to resurrect great historical figures - and I am certain that when that time will come, among the great figures will be our comrade, Lev Iakovlevich. ${ }^{102}$

These were some of the ideas and intellectual currents prevalent among the Bolsheviks when Lenin was wounded in an assassination attempt on 30 August 1918. In the Bolsheviks' response to it, the image of Jesus often appeared, mostly in the suggestion that Lenin and Jesus, in spite of their suffering, were bound to triumph over those who meant them harm. For example, in an article in Petrogradskaia Pravda published two days after

${ }^{100}$ Wiles, “On Physical Immortality”, p. 156.

101 Valerian Murav'ev, "Vseobshchaia proizvoditel'naia matematika”, reprinted in Vselenskoe delo, sbornik, vol. 2, pp. 131-132.

${ }^{102}$ Quoted in M. Ol'minskii, “Kriticheskie stat'i i zametki”, Proletarskaia revoliutsiia, 1 (1931), pp. 149-150. 
the shooting, Lev Sosnovskii, the editor of Bednota, characterized Lenin as a Christlike figure and described him as having deliberately and repeatedly exposed himself to mortal danger, even though, paradoxically, there was nothing Lenin's enemies could do that would extinguish his life. ${ }^{103}$ In language more explicit than Sosnovskii's in its evocation of Christianity, Zinov'ev delivered a speech to the Petrograd Soviet on 6 September in which he termed Lenin's What is to be Done? "the Gospel", and Lenin himself "a leader of divine mercy [. . .] who is born once in five hundred years in the life of humanity". ${ }^{104}$ Lenin's achievements have been so enormous, Zinov'ev concluded, that Lenin has earned a "right to immortality". ${ }^{105}$ Finally, there was published in Proletarskii sbornik in the autumn of 1918 a poem of Iona Brikhnichev, written shortly after Lenin's shooting, which described the leader of the Soviet Union in the following way:

Great leader of the iron host,

Friend and brother of all oppressed people,

Welding together peasants, workers, and soldiers

In the flame of crucifixions

Invincible messenger of peace,

Crowned with the thorns of slander,

Prophet who has plunged his sword into the vampire

Fulfiller of the fiery dream ${ }^{106}$

As emotional as these tributes were, they obviously could not match in intensity the outpouring of adulation and affection that followed Lenin's death in 1924. As Nina Tumarkin has demonstrated, the events immediately following the death - the funeral, the embalming, and the construction of a sarcophagus and a mausoleum in which the body would be preserved marked the emergence of a cult of Lenin that remains to this day one of the sources of the political legitimacy of the Soviet Union. ${ }^{107}$ But just as in 1918, Christian and Christlike imagery was evident in these events.

This was certainly true of several of the tributes to Lenin that were published in the Soviet press. In Pravda, Zinov'ev wrote of how "the genius of Lenin" flew "with wings" over the masses gathered outside the Hall of

${ }^{103}$ L. Sosnovksii, "K pokusheniiu na tov. Lenina", Petrogradskaia pravda (1 September 1918), p. 1.

${ }^{104}$ G. Zinov'ev, “Lenin (Vladimir Il'ich Ul'ianov)”, reprinted in G. Zinov'ev, Sochineniia (Leningrad, 1924), vol. 15, pp. 21, 33.

${ }^{105}$ Ibid., p. 47.

${ }^{106}$ Iona Brikhnichev, "V. I. Leninu”, Proletarskii sbornik (Moscow, 1918), p. 18, reprinted in M. E. O., "Vozhd' mirovoi revoliutsii. Vladimir Il'ich Ul'ianov Lenin", Zheleznyi put', 8 (March, 1919), p. 4.

107 Nina Tumarkin, Lenin Lives! The Lenin Cult in Soviet Russia (Cambridge, MA, 1983), especially pp. 134-206. 
Columns to view Lenin's body. ${ }^{108}$ Lenin's grave, he said, will be "a place of pilgrimage" for people from all parts of the world. ${ }^{109}$ Writing in Izvestiia, the editor, Iurii Steklov, also envisioned the grave as an object of pilgrimage, and added that Lenin's name had "entered the church calendar". ${ }^{110}$ Also in Pravda, Lev Sosnovskii, who was by then the Director of the Department of Agitprop in the Central Committee, wrote that there actually were "two Lenins", one human, the other divine, and that while the Lenin who was human had died, the one who was divine would enjoy eternal life. ${ }^{111}$ With equally impassioned rhetoric, the Chairman of the Soviet Supreme Court, Piotr Stuchka, wrote in the same issue of Pravda that Lenin in his lifetime had achieved the salvation of humanity and was thus a religious leader similar to Jesus, Mohammed, and Buddha, but also superior to them. ${ }^{112}$ Finally, in an official declaration of the Second Congress of Soviets, which was read at Lenin's funeral, Lenin was proclaimed to have been "the leader of a new humanity, the herald, the prophet, and the prince of a new world".

As for the funeral itself, the Bolsheviks could not have been more explicit in evoking an analogy with Jesus when they filled the Hall of Columns with palm branches, which are symbolic of the martyrdom and resurrection of Christ. ${ }^{114}$ Both Krasin and Mel'nikov considered architecture a means of representing the resurrection and infinite prolongation of life, ${ }^{115}$ and Krasin wrote in Izvestiia shortly after the funeral that he believed the mausoleum containing Lenin's body would, upon its completion, equal or even surpass Jerusalem and Mecca in its historical significance. ${ }^{116}$ Although many prominent Bolsheviks, including Trotskii, Bukharin, Kamenev, and Lenin's widow, Krupskaia, opposed, and were even appalled by, the religious symbolism in these events, they were evidently unable to prevent those directly in charge of them from infusing into Lenin's apotheosis the strong suggestion that the founder of the Soviet state bore at least some resemblance to the founder of Christianity.

Unquestionably, there was an element of political calculation in the invocation of Christian images and symbols. When Lenin was wounded in 1918 the Bolsheviks were fighting a civil war against armies committed to

${ }^{108}$ G. Zinov'ev, "Shest' dnei, kotorykh ne zabudet Rossiia", Pravda (30 January 1924), p. 1.

${ }_{109}$ Ibid.

${ }^{110}$ Iu. Steklov, "Mogila Lenina", Izvestiia (27 January 1924), p. 1.

${ }^{111}$ L. Sosnovskii, "Il'ich-Lenin", Pravda (27 January 1924), p. 2.

112 P. Stuchka, "Nash Il'ich", Pravda (27 January 1924), p. 1.

${ }^{113}$ Quoted in A. N. Kotyrev, Mavzolei V. I Lenina (Moscow, 1971), p. 38.

114 Tumarkin, Lenin Lives!, p. 139.

115 Starr, Melnikov, p. 247; L. Krasin, "Arkhitekturnoe uvekovechenie Lenina", Izvestiia (7 February 1924), p. 2.

${ }^{116}$ Krasin, "Arkhitekturnoe uvekovechenie Lenina", p. 2. 
their physical destruction, and when Lenin died in 1924 the survival of the regime was still not an absolute certainty. Notwithstanding the secularism of their ideology, the Bolsheviks may have had no choice but to invoke religious imagery as part of an effort to gain popular support, particularly among classes of the population for which Christianity was still a principal source of attitudes and beliefs about political figures and events. ${ }^{117}$ Several of the Bolsheviks, particularly cynical and unscrupulous ones like Zinov'ev, probably proposed the analogy between Lenin and Jesus without actually believing it. Indeed, one could consider the analogy another of the "red substitutes" the Bolsheviks used to lessen peasant hostility after it became clear to them that religion and religious traditions could not be eradicated instantaneously.

Nevertheless, political calculation alone cannot explain why the Bolsheviks referred to Lenin as the prince of a new world, placed palm branches around his coffin, or envisioned his grave as an object of pilgrimage. In 1918 and in 1924 the Bolsheviks' motives were as much psychological as they were political: by conjuring the symbolism of Gospel Christianity, the Bolsheviks were not only seeking political support but also reassuring themselves that they would win their struggle for survival and fulfill their ultimate objective of building a communist society - in the same way that the earliest Christians had overcome adversity and spread Jesus's message throughout the world. By analogizing their predicament to Jesus's, the Bolsheviks were seeking to gain the confidence that, as leaders of a new and insecure regime, they still lacked.

With Lenin's death, the Jesus analogy acquired - for the first and last time the imprimatur of party legitimacy. The palm branches adorning the Hall of Columns were placed there by a direct order of the Communist Party, and the various encomiums suggesting an analogy or similarity between Lenin and Jesus, even if they were not written in every case by high-ranking Bolsheviks, could not have been published if they had not conformed to the wishes of the Party. Prior to the October Revolution, and even prior to Lenin's death, the decision to invoke the image of Jesus had been a personal one. But in the aftermath of Lenin's death, the invocation of Christlike and Christian imagery became, in a manner of speaking, party doctrine.

Nevertheless, after Lenin's body was safely ensconced in 1930 in a second, and presumably permanent, mausoleum, the image of Jesus, with only a few exceptions, ${ }^{118}$ disappeared from the panorama of Soviet politics.

117 The Bolsheviks, of course, were well aware of how Christian notions of piety and repentance had shaped peasants' feelings towards the Tsars. An analysis of the origins of these feelings can be found in Michael Cherniavsky, Tsar and People: Studies in Russian Myths (New York, 1971), especially pp. 44-71, 190-227.

118 See note 84. 
In explaining this, one might hypothesize that the Stalin cult, because it developed when Stalin was still relatively young, had no need of the motifs of martyrdom and resurrection so prominent in the cult of Lenin. In addition, with its characterization of Stalin as "the greatest genius of mankind", the Stalin cult was so extreme and exaggerated it could not have incorporated a figure such as Jesus, whose attributes, which included divinity, might conceivably have been viewed as superior to Stalin's. ${ }^{119}$

But for nearly a century - from Herzen and Belinskii through the populists, and from the populists through Bogdanov and Lunacharskii, and from Lunacharskii through the attribution of Christlike qualities to Lenin the image of Jesus held a deep fascination for Russian revolutionaries. Whether viewed as a teacher of ethical values, a model of revolutionary heroism, a proto-populist, a proto-proletarian, or a symbol of revolutionary martyrdom and resurrection, Jesus provided legitimacy, inspiration, and a venerable historical pedigree when such things were in very short supply in the more secular, more threatening political environment that these revolutionaries inhabited. Jesus performed great services for the Russian revolutionary movement. His image spoke to its populist phase, which saw itself, and those it championed, as the oppressed. In the early years of Bolshevism, his image spoke to that part of the movement that felt the need to apply to a figure of infinitely larger significance the same terminology (e.g., the word "proletarian") that it applied to itself. And his image spoke to that part of the movement which, in 1918 and 1924, felt compelled to transform its leader into a revolutionary martyr whose cause would survive his suffering and death. In sum, the image of Jesus helped to foster courage, self-assurance, and self-esteem - qualities which, while not subject to analysis of the sort that one applies to political ideology, organization, and strategy, are nevertheless essential to the success of any revolutionary enterprise.

Needless to say, many of the perceptions of Jesus in the writings of Russian revolutionaries were distorted, exaggerated, or simply wrong. For example, very few today would share Lunacharskii's and Bogdanov's view that Jesus was a proletarian and a communist. But the inaccuracy of these perceptions did not detract from their usefulness. Expressed in the form of an analogy, they carried the comforting message that life as a disciple of Jesus was not much different from life as a revolutionary in tsarist Russia, and that just as Jesus's disciples eventually triumphed over the Roman Empire, the disciples of Lenin (or Chernyshevskii or Mikhailovskii or

119 A recent study uncovered no Jesus imagery in the Stalin cult in the years 1929-1939. James Lee Heizer, "The Cult of Stalin, 1929-1939”, (Ph.D., University of Kentucky, 1977). 
Lavrov) would eventually triumph over the Russian Empire. One could even argue that the two empires were analogous.

Finally, it must be said that, prior to 1917, Russian revolutionaries used the images and symbols of Gospel Christianity in a way that carried with it implications for how they might actually govern Russia once they had achieved political power. If, as the revolutionaries argued, Jesus was a populist or a proletarian, it seemed to follow that the Russian peasants and proletariat were Christlike - and thus appropriate for apotheosis as the liberating agent of humanity. Like Jesus, the Russian peasants and proletariat were to deliver all of humanity from its sins and transgressions and (in Berdiaev's Marxian phraseology) to substitute in the world a realm of freedom for a realm of necessity. ${ }^{120}$ But this meant that the peasants and proletariat would be idealized and mythologized to the point where they would be no less an abstraction, no less a product of imagination than the Jesus the revolutionaries extolled as a socialist agitator. In this way, it became easy for the revolutionaries not only to justify everything they did as advancing the interests of the lower classes, but to arrogate to themselves the right to determine what the interests of the lower classes should be. After all, the interests of an abstract and mythologized entity can be more easily manipulated, fabricated, or ignored than those of a real one.

Sadly enough, many of the events in the Soviet Union since the October Revolution seem to bear out Bulgakov's melancholy assertion eight years prior to the Revolution that the adoration with which the Russian revolutionary movement viewed the lower classes could easily become a form of contempt. ${ }^{121}$ From being the agents of their own emancipation, the lower classes became the intended beneficiaries of an emancipation carried out by a self-appointed revolutionary elite. If the populist revolutionaries of the nineteenth century considered the Christlike quality of the Russian peasant justification for carrying out subversive and often violent actions against the state, the Marxist revolutionaries of the twentieth century took what they saw as the singular virtue of the Russian working class as a form of license to practice coercion and terror, usually in the name of the working class and very often with individual workers among the victims.

Of course it would be preposterous to hold Jesus or Gospel Christianity in any way accountable for events that occurred nearly two thousand years later. Nevertheless, the attention Russian Marxists devoted to Jesus and his disciples suggests that the imagery and symbolism of Gospel Christianity played a larger role in the mythology of Russian Marxism, and in the mythology of the Russian revolutionary movement as a whole, than has been generally acknowledged. Although the Russian Marxists, like the

121 Bulgakov, "Heroism and Asceticism", p. 43. 
populists before them, were resolutely hostile to Orthodox Christianity (and to organized religion in general), the Christian idiom they often used was more than just a political ploy, a form of vernacular that the masses would comprehend more readily than the complexities of political ideology. ${ }^{122}$ Rather, this Christian idiom was a consequence and a reflection of a larger national culture in which Christian symbolism continued to play a prominent part even into the twentieth century. Indeed, the Russian intelligentsia during the so-called Silver Age around the turn of the century was to a large extent preoccupied with religious issues and religious questions issues and questions that may in turn have predisposed the many revolutionaries who came from the intelligentsia to draw upon the vast reservoir of religious symbolism in Russian culture in formulating, expressing, and justifying their political choices and commitments. ${ }^{123}$ It may seem odd, at first, that revolutionaries dedicated to the violent and total transformation of a secular state should have concerned themselves with Jesus, an apostle of non-violence and an advocate of otherworldly salvation. But given the culture that the revolutionaries shared with their countrymen, invoking the image of Jesus was actually a very natural thing for them to do.

${ }^{122}$ Examples of such vernacular are easy to find in the words and writings of Soviet leaders after the emergence of a new, less cultured breed of Bolshevik in the early 1930's, a phenomenon that Sheila Fitzpatrick, among others, has explored. (Sheila Fitzpatrick, "Stalin and the Making of a New Elite, 1928-1939", Slavic Review, 38, no. 3 (September 1979), pp. 377-402). Stalin astonished foreign observers by casually referring to God, and Khrushchev on at least one occasion called himself an "apostle" of the communist cause (Adam B. Ulam, Stalin: The Man and His Era (New York, 1973), p. 626, Khrushchev Remembers, translated and edited by Strobe Talbott (Boston, 1970), p. 62). However, Khrushchev's and Stalin's Christian vocabulary - unlike the Christian idiom of earlier revolutionaries - consisted merely of turns of phrase which reflected their peasant upbringing (and, in Stalin's case, several years in an Orthodox seminary) rather than any specific debt to Gospel Christianity.

${ }^{123}$ See, for example, James H. Billington, The Icon and the Axe: An Interpretive History of Russian Culture (New York, 1966), pp. 464-472, 504-518, and Carl Proffer and Ellendea Proffer (eds), The Silver Age of Russian Culture (Ann Arbor, MI, 1971). 